\title{
THE NEXUS BETWEEN HEDGE FUND SIZE AND RISK-ADJUSTED PERFORMANCE
}

\author{
Daniela CATAN ${ }^{*}$ \\ Bucharest University of Economic Studies, Babes-Bolyai University, Romania
}

\begin{abstract}
This paper explores the relationship between hedge fund size and riskadjusted performance employing a data sample of 245 US hedge funds classified into eight different investment strategies. The studied period spans from January 2005 to February 2021, with calculations performed both on the whole coverage period as well as three sub-periods, to isolate the pre-crisis, crisis, and post-crisis funds' behavior. Similar to previous evidence found in the literature, the results reveal an inverse relationship between hedge fund size and risk-adjusted performance (as measured by the Sharpe, Treynor and Black-Treynor ratios) in most of the cases.
\end{abstract}

Keywords: hedge funds, risk-adjusted performance, fund size, fund performance JEL classification: G11, G23, G32.

\section{Introduction}

Starting from the first "market-neutral" portfolio created by Alfred Winslow back in 1949, that could be deemed as the departing point in the development of the vast asset class that we know today, the hedge fund industry witnessed a remarkable increase in total assets, that according to Barclays is estimated to reach an impressive figure of approximately USD 4.5 trillion by the end of 2021. Barth et al. (2021) merged a set of seven public hedge fund data vendors and estimate an even bigger value of worldwide net assets under management (AuM) of USD 5 trillion, and gross assets under management of USD 8.3-8.5 trillion, underlying even more the importance of this asset class and its big "footprint" in the financial markets.

Surviving many recessions along the way, the hedge fund industry benefited from a largely unregulated market, coupled with an expanded use of leverage and various developments in investment strategies. Even now, in the context of the COVID-19 pandemics, hedge fund assets reached record high levels amid investors' hopes for the rebound of the economy as well as increased government spending to support its reboot. In their pursuit of above-average returns, hedge funds usually face a trade-off between prediction accuracy and reaction speed that can be best observed during periods of market turmoil (Dragomirescu - Gaina et. al, 2021).

${ }^{*}$ Corresponding author. Address: Bucharest University of Economic Studies, Mihail Moxa Street, no. 5-7, 010961, Bucharest, Romania. E-mail: daniela.catan@econ.ubbcluj.ro 
Basile (2016) defines hedge funds as "collective investment vehicles (CIVs) which, through active investment techniques and often with high financial leverage, aim to achieve positive risk-adjusted returns, irrespective of the trends of the target markets". A particular characteristic of hedge fund managers is the wide margin of discretion in the adoption of hedging or investment strategies that are regarded to be suitable to the followed objectives. This enables hedge fund managers to deliver aboveaverage returns, that in turn, draws interest from a broad and increasingly sophisticated set of investors. Being aware of the operational and regulatory leeway benefiting hedge funds, lately, investors have been seeking more transparency from the funds they choose to invest in, and thus, industry regulation has moved into the public's attention. This goes hand in hand with the investors' appreciation and curiosity towards hedge funds' characteristics that should be analyzed prior to investing. While choosing a certain fund, one of the first dimensions being examined is its size, along with the return and risk attributes.

When it comes to the valuation models for explaining hedge funds returns, Lhabitant (2004) identifies two broad categories: absolute pricing models that include equilibrium models in conjunction with several macro-economic models, and relative value models, that price hedge funds relative to market or any other risk factors. The latter category could be further classified into several distinct components based on the factors used to explain the hedge fund returns, namely: explicit macro factors, explicit index factor models, explicit micro factor models, and implicit factor models (Amenc et al., 2003). A similar classification is suggested by Connor (1995), by identifying three broad factor categories, namely: macroeconomic factor models, fundamental factor models, and statistical factor models. Explicit micro-factor models are several factors that refer to fund specific features, such as age, size, fund manager tenure and performance fees (Stafylas et al., 2016). As it is presented below (Literature review section), there are a handful of studies that deal with this issue (e.g. Gregoriou and Rouah, 2002, Goetzmann, Ingersoll, and Ross, 2003, Harri and Brorsen, 2004, Getmansky, 2004, Jones, 2007, Clare et al., 2015).

The relationship between hedge fund size and its risk-adjusted performance has been a topic of growing concern for practitioners and academics alike. Although, the common belief might suggest that a larger size entails better performance and hence might pose a more attractive proposition, with investors being frequently lured by the growing asset base statistics, that are pompously advocated in funds' promotion materials, the academic studies on the matter are rather contradictory. The majority of studies analyzing the relationship between the size and performance conclude that there is a negative relationship, with smaller funds outperforming their larger peers (e.g. Schneeweis et al. 2002, Harri and Brorsen, 2004, Agarwal et al., 2004, Ammann and Moerth, 2005). Nevertheless, there are some studies that point towards a non-negative or even positive relationship between size and performance (e.g. Gregoriou and Rouah, 2002, Koh et al., 2003, Amenc and Martellini, 2003, Getmansky, 2004). The issue discussed here bears at least a twofold dimension.

On the one hand, it could be argued that investment opportunities narrow as assets increase, confining managers to choose among positions with high liquidity. Thus, they shun away from small-capitalization stocks that quite often offer the prospective of finding little-known companies with great upside potential, as these tend to be less covered by professional equity research analysts. This limitation curbs hedge fund performance once its asset base expands. Another argument 
supporting the underperformance of large funds in comparison to their smaller peers is the one related to transaction costs, that inevitably increase, as a higher number of orders must be executed. This gives rise to the so-called diseconomies of scale, that is a phenomenon encountered not only across the asset management business, but across most industries, occurring when a firm experiences increasing marginal costs per additional unit of output. On the other hand, the structure of the performance fee as well as the management fees, might provide the incentive for better discipline while the asset base expands. Here it's worth mentioning that studies have revealed that hedge funds' compensation structures often fail to align managers' incentives with investors' interests as management fees tend to comprise a larger portion of total compensation for fund managers as their company grows (Kouwenberg et al., 2007, Broeders et al., 2019, Escobar-Anel et al., 2020). In other words, as funds grow, managers may have fewer incentives to improve fund performance because most of their compensation comes from the asset-based management fee (Gao et al., 2020).

At the same time, larger funds often benefit from operational synergies, as more resources are invested in the development of technology, regulation, and compliance areas. Moreover, besides fees, liquidity and a smaller universe of available stocks to invest in, the investing style of the fund can also make a difference. A fund with high turnover will be more adversely affected by liquidity issues than a fund with a long-term or hold strategy.

This curious combination of variables affecting the performance of one of the most intriguing asset management branches, has spurred my interest to research the topic and analyze more closely the relationship between the size and the riskadjusted performance of hedge funds. Hence, this paper contributes to the existing strand of literature of hedge funds' performance analysis by studying the size impact on hedge funds' risk-adjusted returns on a more recent period compared to the studies that already exist on the subject, as well as three-sub-periods, one of them comprising a part of the COVID-19 crisis.

The size impact on the risk-adjusted performance is tested on a database comprised of 245 US hedge funds, classified into eight different investment strategies covering the period of January 2005 - February 2021. To isolate the precrisis, crisis, and post-crisis periods, the testing is also performed on three subperiods. The latest studied sub-period (April 2009 - February 2021) also comprises a part of the COVID-19 crisis, hence making it possible to test the relationship during the latest pandemic that affected the global economy and financial markets in an unprecedented manner.

To highlight the size influence, the hedge funds are divided into quartiles based on their AuM level. The results confirm the conclusions from the literature (e.g.: Schneeweis et al. 2002, Harri and Brorsen, 2004, Agarwal et al., 2004, Ammann and Moerth, 2005), namely, an inverse relationship between size and risk-adjusted performance, for most of the cases. The portfolio that was constructed in the first quartile, delivered the highest return levels and the highest risk-adjusted performance values, in most of the cases. While the portfolio that was constructed in the fourth quartile, delivered, mostly, the lowest values for the risk-adjusted performance measures. 


\section{Literature review}

The analysis of the relationship between size and hedge fund performance can have two possible implications. From the investor perspective, it is a decision factor that must be carefully weighted in before the investment action. Meanwhile, from the fund manager's viewpoint, the degree to which size impacts performance is relevant when deciding the optimal fund size to be chosen. A vast strand of literature documents that funds (both of mutual and hedge type) that are too large cannot be effectively managed (Liang, 1999, Indro et al., 1999, Chen et al., 2004, Pollet et al., 2008). This argument can also be traced to events from the hedge fund industry noticed along its history. For example, in 1998 the two largest hedge funds were the Quantum Fund and the Tiger Fund, and both experienced lackluster performance in 1998 and 1999. More than that, Tiger Management closed down in March 2000, further justifying the inverse relationship between size and performance.

Gregoriou and Rouah (2002) studied the relationship between size (defined as the total AuM at the start of the calculation period) of hedge funds and their performance by employing the Pearson's correlation coefficient and Spearman's rank correlation, from January 1994 to December 1999 and found no statistical significance. Thus, authors concluded that the size of a hedge fund (and of a fund of hedge funds) has no impact on its performance. Similar results were observed for the Asian hedge funds (Koh et al., 2003).

During the same year, an interesting study conducted by Hedges (2003) revealed slightly different results. The study covered the period of 1995-2002 and used three equally-weighted size-mimicking portfolios of monthly returns. The hedge funds were classified by size level into three distinct buckets: small, medium and large. The author showed that smaller funds performed better than larger funds. However, mid-sized funds reported the worst results. This finding suggested the notion of 'mid-life crises' for hedge fund managers as mid-size firms tend to be inefficient in terms of exploiting opportunities and processes to reach optimum performance (Stafylas et al., 2015).

On the other hand, Harri and Brorsen (2004) find a strong negative relationship between hedge fund size, measured as the logarithm of the market capitalization and fund returns. Authors test the hypothesis that the source of hedge fund returns comes from the existence and exploitation of the inefficiencies in asset pricing on the debt, equity, currency, and commodities markets. Since these inefficiencies have a fixed size, allocating more money to exploit a particular inefficiency would cause a decrease in returns. This hypothesis is also supported by the fact that some funds are closed to new investment.

Getmansky (2004) performs a regression on the TASS database that includes the size squared as a factor and finds a positive and concave relationship between current performance and past asset size is found. This suggests that an investor should select hedge funds that are near their optimal size. Agarwal, Daniel and Naik (2006), and Goetzmann, Ingersoll, and Ross (2003) find a similar relationship.

Moreover, Gregoriou et al. (2005) point that a hedge fund's risks increase proportionately with its AuM due to the use of specialized strategies that naturally impose a certain optimal size level beyond which it becomes increasingly challenging 
to keep the same strategy or have the same opportunities for execution. As managers are aware of the trade-off between size and performance, they are inclined to close their funds for further investments as soon as a target size is reached.

Furthermore, Jones (2007) used simple returns to gauge performance and discovered that smaller, younger funds tend to outperform larger, older hedge funds. The results were obtained by creating three size-based hedge fund indices by combining the hedge fund performance records from the Hedge Fund Research, HedgeFund.net, Morningstar's Altvest, and Barclays Global HedgeSource databases. The author computed monthly returns and size levels for each fund from the database from January 1996 through December 2007 and grouped the funds based on their current size, hence constructing the three indices representative of the AuM level. The annualized return for the studied period for the small funds was of $16.01 \%$, while for the largest funds was of $11.50 \%$.

The argument that small hedge funds are more likely to outperform large funds has also been supported by the results of Gao et al. (2019). The authors employed data from the Lipper TASS and HFR databases and separated the hedge funds into three size groups: less than $\$ 10$ million of AuM (small), $\$ 10$ million to $\$ 100$ million (medium), and more than $\$ 100$ million (large). Their sample included performance data from January 1994 to December 2016. Although the study found that younger funds are inclined to outperform their older peers, age is not so relevant for smaller hedge funds.

Evidence shows that smaller hedge funds keep outpacing their larger peers even during times of crisis. Clare et al. (2015) studies the relationship between the hedge fund performance and size using a sample of over 7,200 funds during the period of 1995 to 2014 and discover a strong, negative relationship between hedge fund performance and size. More than that, authors also find that rather than dissipating during the two recent periods of financial crisis (the early 2000s' postdotcom bubble and the Global Financial Crisis), other things equal, investors would have been better off with smaller hedge funds than with large ones during these crisis periods.

Yin (2012) explores the impact of the standard compensation contract in the hedge fund industry in aligning managers' incentives with investors' interests and proves empirically that managers' compensation increases as fund assets grow, even when diseconomies of scale in fund performance exist. Under this framework, managers' compensation is maximized at a much larger fund size than is optimal for fund performance. Yet to avoid capital outflows, managers are also incentivized to hinder fund growth to sustain style-average performance.

\section{Methodology}

The departing point of the research methodology used in this paper is the concept of the market model. The underlying idea behind the market model is that the rate of return "surprise" of any security is proportional to the return "surprise" of the market index portfolio, and the extent of the security's responsiveness to market changes, as measured by $\beta$, plus a firm-specific surprise. The market model equation divides returns into firm-specific and systematic components. The market model is often used inter-changeably with the single-index model. First suggested 
by Sharpe (1966), the index model offers insight into portfolio diversification. The excess return on the portfolio of stocks could be written as:

$$
r_{p}=\alpha_{p}+\beta_{p} r_{M}+\varepsilon_{p},
$$

where $r_{p}$ - excess return of the portfolio,

$\beta_{p}$ - Beta of the portfolio $p$,

$r_{M}$ - excess return of the market.

The index model is estimated by applying regression analysis to excess rates of return. The slope of the regression curve represents the beta of an asset, whereas the intercept is the asset's alpha during the sample period. The regression line is also called the security characteristic line (SCL). The regression beta is equivalent to the CAPM beta, except that the regression uses actual returns and the CAPM is specified in terms of expected returns (Bodie et al., 2011).

$$
E\left(R_{i}\right)=R_{f}+\beta_{i}\left[E\left(R_{M}\right)-R(f)\right]
$$

where, $E\left(R_{i}\right)$ - expected return of individual security $i$.

The expected return-beta relationship can be portrayed graphically as the security market line (SML). The SML offers a benchmark for the evaluation of investment performance. Given the risk of an investment, measured by its beta, the SML provides the required rate of return necessary to compensate investors for both risk as well as the time value of money. Therefore, in market equilibrium, the "fairly priced" assets should lie on the SML. If a stock is underpriced, it will provide an expected return in excess of the fair return given by the SML. Underpriced stocks therefore plot above the SML. In contrast, overpriced stocks plot below the SML. The difference between the fair and expected rates of return on a stock is reflected in the stock's alpha $(\alpha)$.

Furthermore, one category of risk-adjusted performance measures comes from the differential return developed by Michael Jensen (1968). The scope of this technique is to compare the return expected by the CAPM and the actual realized return.

$$
\alpha_{p}=R_{p}-R_{p}^{C A P M}
$$

In addition, Jensen has also developed a method to determine whether the differential return had appeared by chance or if it has a statistical significance by running the following regression:

$$
R_{p}-R_{f}=\alpha_{p}+\beta_{p}\left(R_{M}-R_{f}\right)+\varepsilon
$$

The error term shows how well the regression fits the data - a low error indicates a strong relationship, while a high error indicates a weak relationship. The intercept term $\left(\alpha_{p}\right)$ indicates whether the evaluated portfolio has an above-average or below-average performance. If $\alpha_{p}$ is positive, the portfolio has an above-average performance, respectively if it is negative, then the performance is below-average. 
Note that we cannot classify portfolios based solely on the alpha measure, because a risk measure needs to be included as well. Black-Treynor's ratio divides Jensen's $\alpha$ to the systematic risk and offers a measure to evaluate portfolio managers based on their stock-picking ability:

$$
R_{B T}=\frac{\alpha_{p}}{\beta_{p}}
$$

The second category of risk-adjusted performance measures could be classified as the returns per unit of risk ratios. The return per unit of risk method was simultaneously developed with the CAPM. Jack Treynor (1965) and William Sharpe (1966) have used the implications of the CAPM for rating performance managers.

The Sharpe ratio, also known as the reward-to-variability ratio divides the realized portfolio return $\left(\bar{R}_{p}\right)$ in excess of the risk-free rate $\left(\bar{R}_{f}\right)$ to the variability of return measured by the standard deviation $\left(\sigma_{p}\right)$.

$$
S R=\frac{\bar{R}_{p}-\bar{R}_{f}}{\sigma_{p}}
$$

As the standard deviation is a measure of total risk, Sharpe Ratio should be used when evaluating portfolios that include the majority of the manager's invested assets. On the other hand, if we want to evaluate portfolios that represent just a fraction of the invested funds, a better risk measure is the beta coefficient.

The Treynor ratio or ratio of reward divides the realized portfolio return in excess of the risk-free rate to the volatility of return measured by the portfolio beta.

$$
T R=\frac{\bar{R}_{p}-\bar{R}_{f}}{\beta_{p}}
$$

The greater the Sharpe and Treynor ratio is, the more performant is the portfolio. However, managers should be careful when selecting the appropriate benchmark index for the evaluated portfolio, as in a well-known study by Roll (1977) it proved to affect the risk-adjusted ratios.

In addition to the risk-adjusted performance measures that were computed for the employed data sample, the monthly, annualized return, standard deviation, and variance, as well as Beta level was calculated:

$$
\begin{gathered}
R_{p}=E\left(R_{p}\right)=\sum_{i=1}^{n} w_{i} E\left(R_{i}\right), \\
R_{a n n}=\left(1+R_{p}\right)^{12}-1, \\
V\left(R_{p}\right)=\sum_{i=1}^{N} w_{i}^{2} V\left(R_{i}\right)+\sum_{i=1}^{N} \sum_{j=1}^{N} w_{i} w_{j} \operatorname{Cov}\left(\begin{array}{c}
\left.R_{i} R_{j}\right), \\
i \neq j
\end{array}\right. \\
\sigma_{p}=\sqrt{V\left(R_{p}\right)}, \\
\beta_{p}=\frac{\operatorname{Cov}\left(R_{p} R_{m}\right)}{\operatorname{Var}\left(R_{m}\right)}
\end{gathered}
$$

where

$w_{i}$ - weight of individual security $i$,

$R_{p}$ - average return of the portfolio,

$E\left(R_{i}\right)$ - expected return of individual security $i$, 
$R_{\text {ann }}$ - annualized return,

$\operatorname{Var}\left(R_{i}\right)$ - variance of individual security $i$,

$\operatorname{Var}\left(R_{m}\right)$ - variance of market return,

$\operatorname{Cov}\left(R_{i} R_{j}\right)$ - covariance between the return of security $i$ and the return of security $j$,

$\operatorname{Cov}\left(R_{p} R_{m}\right)$ - covariance between the portfolio return and market return,

$\sigma_{p}$ - standard deviation of the portfolio,

$\beta_{p}$ - Beta of the portfolio.

Moreover, to study the size effect on the hedge funds' risk-adjusted performance, the dataset was split into quartiles by Assets-under-Management (AuM), as of the latest available data levels (reported in February 2021). The calculations were performed for the whole studied period, namely: January 2005 - February 2021, as well as for the following sub-periods: January 2005 - July 2007 (to isolate the funds' performance during the pre-crisis period), August 2007 - March 2009 (to isolate the funds' performance during the crisis period), and April 2009 - February 2021 (to isolate the funds' performance during the post-crisis period). After grouping the funds in accordance with their size level, equal-weighted portfolios have been constructed inside each quartile, which were evaluated from a risk-adjusted performance using the measures that were described above.

\section{Data and descriptive statistics}

The hedge fund sample used in this study is from the eVestment database. A Nasdaq platform, eVestment provides traditional and hedge fund data for public and private markets. The database used for this study consists of net-of-fee monthly returns for 245 hedge funds from the United States. The sample period spans from January 2005 to February 2021. Starting from the US hedge fund universe, as classified in the eVestment database, several filters were applied to arrive at the final studied database, namely: the selected funds should have at least a 5-year period of reported financial history, which among other characteristics, should also comprise the incentive and management fees. The selected hedge funds can be classified into eight categories, as per the pursued investment strategy, specifically: Relative Value, Fundamental Long/Short Equity, Fundamental Long Only Equity, Macro-Quantitative, Managed Futures Quantitative, Fund of Funds, Event-Driven, and Multi-Strategy. The data sample also contains the monthly net asset value and the maximum Drawdown values.

Table 1 - Strategies' definitions

\begin{tabular}{|l|l|}
\hline Investment Strategy & Definition (eVestment) \\
\hline Relative Value & $\begin{array}{l}\text { Hedge funds that expect returns that compare to a } \\
\text { preferred benchmark. }\end{array}$ \\
\hline $\begin{array}{l}\text { Fundamental Long/Short } \\
\text { Equity }\end{array}$ & $\begin{array}{l}\text { lternative direct funds and replication funds that } \\
\text { measure an equity security's intrinsic value by examining } \\
\text { related economic, financial and other qualitative and } \\
\text { quantitative factors, and then make long and short trades } \\
\text { based on those assessments. }\end{array}$ \\
\hline
\end{tabular}




\begin{tabular}{|l|l|}
\hline Investment Strategy & Definition (eVestment) \\
\hline $\begin{array}{l}\text { Fundamental Long Only } \\
\text { Equity }\end{array}$ & $\begin{array}{l}\text { Alternative direct funds and replication funds that } \\
\text { measure an equity security's intrinsic value by examining } \\
\text { related economic, financial and other qualitative and } \\
\text { quantitative factors, and then make long only trades } \\
\text { based on those assessments. }\end{array}$ \\
\hline Macro-Quantitative & $\begin{array}{l}\text { Alternative direct funds that use mathematical and } \\
\text { technical models to identify opportunities in markets } \\
\text { showing trends or momentum across asset classes or } \\
\text { individual securities. }\end{array}$ \\
\hline Managed Futures & $\begin{array}{l}\text { Alternative direct funds that use mathematical and technical } \\
\text { models to identify opportunities in broad financial } \\
\text { derivatives, commodities, commodity derivatives and FX. }\end{array}$ \\
\hline Fund of Funds & $\begin{array}{l}\text { Alternative fund of funds hold a portfolio of alternative } \\
\text { funds rather than investing directly in shares, bonds or } \\
\text { other securities. }\end{array}$ \\
\hline Event-Driven & $\begin{array}{l}\text { Alternative direct funds and replication funds that take } \\
\text { positions in securities with the expectation of specific } \\
\text { events to realize the value of their current positions. }\end{array}$ \\
\hline Multi-Strategy & $\begin{array}{l}\text { Alternative direct funds and replication funds that run } \\
\text { several different strategies in-house that contribute to the } \\
\text { total performance of the fund. }\end{array}$ \\
\hline
\end{tabular}

Source: eVestment database (Universes and Definitions Guidebook).

Table 2 summarizes the monthly net-of-fee returns for the data sample and its associated summary statistics. From January 2005 to February 2021, all hedge funds included in the sample earned an average net-of-fee return of $0.92 \%$ per month. In terms of the mean fund age, the hedge funds included in the data set had, on average, 322 months, or 26.8 years, while the funds belonging to the $90^{\text {th }}$ percentile reached 565.2 months, or 47 years. The management fee, which is an annual fee charged by the manager to cover the operating costs of the investment vehicle and is applied to the net asset value, was on average $1.54 \%$, stretching to $2 \%$ in the $90^{\text {th }}$ percentile. Meanwhile, the incentive fee, also known as the performance fee, which is viewed as a reward for positive returns, reached, on average, $15 \%$ applied to the fund's profits.

Table 2 - Descriptive statistics

\begin{tabular}{|l|c|c|c|c|c|c|c|}
\hline & Mean & STD & $\mathbf{1 0 \%}$ & $\mathbf{2 5 \%}$ & Median & $\mathbf{7 5 \%}$ & $\mathbf{9 0 \%}$ \\
\hline Fund monthly return, \% & 0.92 & 4.80 & -3.41 & -0.84 & 0.73 & 2.56 & 5.37 \\
\hline Fund size (\$,m) & 83,736 & 624,040 & 63 & 223 & 762 & 4,649 & 36,341 \\
\hline Fund age (month) & 321.66 & 235.48 & 120.0 & 168.0 & 264.0 & 384.0 & 565.2 \\
\hline Management fee (\%) & 1.54 & 1.81 & 0.90 & 1.00 & 1.50 & 1.75 & 2.00 \\
\hline Incentive fee (\%) & 15.41 & 7.69 & 0.00 & 10.00 & 20.00 & 20.00 & 20.00 \\
\hline
\end{tabular}

Source: Author's computations based on eVestment data. 
When it comes to the AuM level, the average hedge fund reported an asset base of USD 83.7 billion, while the median size level was of USD 0.76 billion. As it can be observed, the distribution of the AuM size is heavily skewed to the right, as there are a few, very large hedge funds, boasting an asset-base of over USD 1 trillion such as, Wellington Management Company, J.P. Morgan Investment Management Inc. and BlackRock. As a matter of fact, the latter is the world's largest asset manager with total assets under management of $\$ 9.46$ trillion as of September 30, 2021. Table 3 summaries the size intervals obtained after dividing the dataset into quartiles by AuM.

Table 3 - AuM Quartiles

\begin{tabular}{|l|l|l|l|l|}
\hline Quartile & 1 - Small & 2 - Moderate & 3 - Expanded & 4 - Large \\
\hline AuM intervals & $\begin{array}{l}\text { Less than } \$ 225 \\
\text { million }\end{array}$ & $\begin{array}{l}\text { \$225 million to } \\
\$ 762 \text { million }\end{array}$ & $\begin{array}{l}\text { \$762 million to } \\
\$ 4.6 \text { billion }\end{array}$ & $\begin{array}{l}\$ 4.6 \text { billion } \\
\text { to } \$ 9 \text { trillion }\end{array}$ \\
\hline
\end{tabular}

Source: Author's computations based on eVestment data.

Furthermore, the S\&P500 was used as a proxy for the market return, with an average value for the analyzed period (January 2005 - February 2021) of $0.86 \%$, while the ML 3-month T-Bills was used as a proxy for the return on the risk-free rate asset, reporting an average value of $0.11 \%$ for the sample period.

\section{Results}

Table 4a presents the traditional performance metrics for the four portfolios representative of the size quartiles during the whole analyzed period, namely January 2005 - February 2021. As it can be noticed, the average portfolio return reached the highest value, of $0.75 \%$ in the case of the lowest (SMALL) quartile, hence validating the inverse relationship between fund size and return. The same could be said about the funds' registered cumulative return. From January 2005 to February 2021, hedge funds from the first quartile earned $310.6 \%$ in net return, more than doubling the returns from the fourth quartile. It's important to note, that while the returns decreased as asset-base grew, the risk, measured as standard deviation and $\beta$, decreased. Thus, while smaller funds deliver better returns, they also pose a higher level of risk. It's interesting to observe that this is not the case for the MODERATE vs. EXPANDED portfolios, which are the second and the third quartile, respectively. The portfolio formed from the funds in the second quartile provides higher return and lower risk compared to the third quartile.

Table 4a - Performance metrics. January 2005 - February 2021

\begin{tabular}{|l|l|c|c|l|c|}
\hline Quartile & Size & $\begin{array}{l}\text { Average port- } \\
\text { folio return }\end{array}$ & $\begin{array}{l}\text { Standard } \\
\text { deviation }\end{array}$ & $\begin{array}{l}\text { Cumulative } \\
\text { Return }\end{array}$ & $\boldsymbol{\beta}$ \\
\hline SMALL & $\begin{array}{l}\text { Less than } \\
\text { \$225 million }\end{array}$ & $0.75 \%$ & $2.16 \%$ & $310.63 \%$ & 0.42 \\
\hline MODERATE & $\begin{array}{l}\text { \$225 million to } \\
\text { \$762 million }\end{array}$ & $0.64 \%$ & $1.62 \%$ & $235.05 \%$ & 0.31 \\
\hline
\end{tabular}




\begin{tabular}{|l|l|c|c|c|c|}
\hline Quartile & Size & $\begin{array}{l}\text { Average port- } \\
\text { folio return }\end{array}$ & $\begin{array}{l}\text { Standard } \\
\text { deviation }\end{array}$ & $\begin{array}{l}\text { Cumulative } \\
\text { Return }\end{array}$ & $\boldsymbol{\beta}$ \\
\hline EXPANDED & $\begin{array}{l}\text { \$762 million to } \\
\$ 4.6 \text { billion }\end{array}$ & $0.63 \%$ & $1.93 \%$ & $225.76 \%$ & 0.40 \\
\hline LARGE & $\begin{array}{l}\text { \$4.6 billion to } \\
\$ 9 \text { trillion }\end{array}$ & $0.42 \%$ & $1.28 \%$ & $121.89 \%$ & 0.26 \\
\hline \multicolumn{2}{|c|}{ Average } & $0.61 \%$ & $1.75 \%$ & $223.33 \%$ & 0.35 \\
\hline
\end{tabular}

Source: Author's computations based on eVestment data.

Table $4 \mathrm{~b}$ presents the risk-adjusted performance for the four portfolios representative of the size quartile during the whole analyzed period, namely January 2005 - February 2021. One can observe that the SMALL portfolio offered the highest alpha level. When it comes to the Sharpe, Treynor, and Black-Treynor ratios, the MODERATE portfolio leads the group. The LARGE portfolio, which comprises the funds with the highest level of AuM, delivered the lowest risk-adjusted results and registered the lowest alpha level.

Table 4b - Risk-adjusted metrics. Period: January 2005 - February 2021

\begin{tabular}{|l|c|c|c|c|}
\hline \multicolumn{1}{|c|}{ Quartile } & Alpha & Sharpe ratio & Treynor ratio & Black-Treynor \\
\hline SMALL & $0.33 \%$ & 0.30 & $1.54 \%$ & $0.79 \%$ \\
\hline MODERATE & $0.29 \%$ & 0.33 & $1.69 \%$ & $0.94 \%$ \\
\hline EXPANDED & $0.22 \%$ & 0.27 & $1.30 \%$ & $0.55 \%$ \\
\hline LARGE & $0.12 \%$ & 0.24 & $1.20 \%$ & $0.46 \%$ \\
\hline \multicolumn{1}{|c|}{ Average } & $0.24 \%$ & 0.28 & $1.43 \%$ & $0.69 \%$ \\
\hline
\end{tabular}

Source: Author's computations based on eVestment data.

Furthermore, the performance of the four portfolios was also analyzed by sub-periods in order to isolate the pre-crisis, crisis, and post-crisis behavior. During the pre-crisis period (January 2005 - July 2007), the average monthly portfolios' return was of $0.38 \%$. Just as in the previous analysis that comprised the whole sample period, the SMALL portfolio is still placed at the top of the group, with a monthly return of $0.50 \%$, followed by the EXPANDED portfolio delivering a return of $0.39 \%$. The cumulative performance also follows a similar ranking, with the SMALL portfolio, scoring a $16.69 \%$ return. We can notice that, as expected, risk level decreases as asset base grows, with the SMALL portfolio, being the most risky asset, if we were to measure it by its standard deviation and Beta level, while the LARGE portfolio bears the smallest level of risk. These results are presented in the Table $5 a$. 
Table 5a - Performance metrics. Pre-crisis period: January 2005 - July 2007

\begin{tabular}{|c|c|c|c|c|c|}
\hline Quartile & Size & $\begin{array}{l}\text { Average } \\
\text { portfolio } \\
\text { return }\end{array}$ & $\begin{array}{l}\text { Standard } \\
\text { deviation }\end{array}$ & $\begin{array}{l}\text { Cumulative } \\
\text { Return }\end{array}$ & $\beta$ \\
\hline SMALL & $\begin{array}{l}\text { Less than } \\
\$ 225 \text { million }\end{array}$ & $0.50 \%$ & $0.99 \%$ & $16.69 \%$ & 0.33 \\
\hline MODERATE & $\begin{array}{l}\text { \$225 million to } \\
\$ 762 \text { million }\end{array}$ & $0.37 \%$ & $0.52 \%$ & $12.11 \%$ & 0.18 \\
\hline EXPANDED & $\begin{array}{l}\$ 762 \text { million to } \\
\$ 4.6 \text { billion }\end{array}$ & $0.39 \%$ & $0.46 \%$ & $12.85 \%$ & 0.17 \\
\hline LARGE & $\begin{array}{l}\$ 4.6 \text { billion to } \\
\$ 9 \text { trillion }\end{array}$ & $0.25 \%$ & $0.23 \%$ & $8.13 \%$ & 0.08 \\
\hline \multicolumn{2}{|c|}{ Average } & $0.38 \%$ & $0.55 \%$ & $12.45 \%$ & 0.19 \\
\hline
\end{tabular}

Source: Author's computations based on eVestment data.

Additionally, Table 5b represents the risk-adjusted performance for the four portfolios during the pre-crisis period. The SMALL portfolio is the only one that manages to deliver a positive alpha, albeit it is very close to zero, while the other portfolios register negative alpha values. The Sharpe, Treynor, and Black-Treynor ratios also have the highest values for the SMALL portfolio.

Table 5b - Risk-adjusted metrics. Pre-crisis period: January 2005 - July 2007

\begin{tabular}{|l|c|c|c|c|}
\hline \multicolumn{1}{|c|}{ Quartile } & Alpha & Sharpe ratio & Treynor ratio & Black-Treynor \\
\hline SMALL & $0.02 \%$ & 0.16 & $0.49 \%$ & $0.06 \%$ \\
\hline MODERATE & $-0.05 \%$ & 0.05 & $0.15 \%$ & $-0.28 \%$ \\
\hline EXPANDED & $-0.03 \%$ & 0.10 & $0.27 \%$ & $-0.15 \%$ \\
\hline LARGE & $-0.12 \%$ & -0.41 & $-1.21 \%$ & $-1.63 \%$ \\
\hline \multicolumn{1}{|c|}{ Average } & $-0.04 \%$ & -0.02 & $-0.07 \%$ & $-0.50 \%$ \\
\hline
\end{tabular}

Source: Author's computations based on eVestment data.

In the case of the Great Financial Crisis period, the only portfolio that managed to not enter in the negative territory was the MODERATE portfolio. It also recorded the smallest value of standard deviation and Beta level, as it is represented in the Table $6 a$. 
Table 6a - Performance metrics. GFC period: August 2007 - March 2009

\begin{tabular}{|l|l|l|c|c|c|}
\hline Quartile & Size & $\begin{array}{l}\text { Average } \\
\text { portfolio } \\
\text { return }\end{array}$ & $\begin{array}{l}\text { Standard } \\
\text { deviation }\end{array}$ & $\begin{array}{l}\text { Cumulative } \\
\text { Return }\end{array}$ & $\boldsymbol{\beta}$ \\
\hline SMALL & $\begin{array}{l}\text { Less than } \\
\$ 225 \text { million }\end{array}$ & $-0.03 \%$ & $1.80 \%$ & $-0.97 \%$ & 0.24 \\
\hline MODERATE & $\begin{array}{l}\text { \$225 million to } \\
\$ 762 \text { million }\end{array}$ & $0.03 \%$ & $1.09 \%$ & $0.47 \%$ & 0.15 \\
\hline EXPANDED & $\begin{array}{l}\$ 762 \text { million to } \\
\$ 4.6 \text { billion }\end{array}$ & $-0.49 \%$ & $1.88 \%$ & $-9.66 \%$ & 0.27 \\
\hline LARGE & $\begin{array}{l}\text { \$4.6 billion to } \\
\$ 9 \text { trillion }\end{array}$ & $-0.18 \%$ & $1.13 \%$ & $-3.59 \%$ & 0.16 \\
\hline \multicolumn{2}{|c|}{ Average } & $0.38 \%$ & $-0.17 \%$ & $1.47 \%$ & $-3.4 \%$ \\
\hline
\end{tabular}

Source: Author's computations based on eVestment data.

In the Table $6 \mathrm{~b}$, it could be observed that the Sharpe and Treynor ratios had negative values for all of the portfolios, yet the smallest negative value was registered by the SMALL portfolio. It also managed to deliver the highest monthly alpha of $0.43 \%$ and the highest Black-Treynor ratio of $1.79 \%$.

Table 6b - Risk-adjusted metrics. GFC period: August 2007 - March 2009

\begin{tabular}{|l|c|c|c|c|}
\hline \multicolumn{1}{|c|}{ Quartile } & Alpha & Sharpe ratio & Treynor ratio & Black-Treynor \\
\hline SMALL & $0.43 \%$ & -0.13 & $-0.99 \%$ & $1.79 \%$ \\
\hline MODERATE & $0.24 \%$ & -0.16 & $-1.18 \%$ & $1.60 \%$ \\
\hline EXPANDED & $0.07 \%$ & -0.37 & $-2.52 \%$ & $0.26 \%$ \\
\hline LARGE & $0.07 \%$ & -0.34 & $-2.34 \%$ & $0.44 \%$ \\
\hline \multicolumn{1}{|c|}{ Average } & $0.20 \%$ & -0.25 & $-1.76 \%$ & $1.02 \%$ \\
\hline
\end{tabular}

Source: Author's computations based on eVestment data.

Following the GFC, it was interesting to analyze how the hedge funds performed in the post-crisis period and whether larger funds started to provide better results in comparison to smaller funds. In terms of the average portfolio return, the situation hasn't changed much, with the SMALL portfolio still earning more than its larger-sized peers. It also displayed the highest amount of risk. Thus, it could be said that returns diminish as asset base increases, with the exception noticed for the EXPANDED vs. the MODERATE portfolio ( $0.84 \%$ vs. $0.78 \%$, respectively), as it can be noticed in the Table 7a. 
Table 7a - Performance metrics. Post-crisis period: April 2009 - February 2021

\begin{tabular}{|c|c|c|c|c|c|}
\hline Quartile & Size & $\begin{array}{l}\text { Average } \\
\text { portfolio } \\
\text { return }\end{array}$ & $\begin{array}{l}\text { Standard } \\
\text { deviation }\end{array}$ & $\begin{array}{l}\text { Cumulative } \\
\text { Return }\end{array}$ & $\beta$ \\
\hline SMALL & $\begin{array}{l}\text { Less than } \\
\$ 225 \text { million }\end{array}$ & $0.92 \%$ & $2.35 \%$ & $255.34 \%$ & 0.50 \\
\hline MODERATE & $\begin{array}{l}\$ 225 \text { million to } \\
\$ 762 \text { million }\end{array}$ & $0.78 \%$ & $1.80 \%$ & $197.48 \%$ & 0.39 \\
\hline EXPANDED & $\begin{array}{l}\$ 762 \text { million to } \\
\$ 4.6 \text { billion }\end{array}$ & $0.84 \%$ & $2.07 \%$ & $219.54 \%$ & 0.46 \\
\hline LARGE & $\begin{array}{l}\$ 4.6 \text { billion to } \\
\$ 9 \text { trillion }\end{array}$ & $0.54 \%$ & $1.40 \%$ & $112.85 \%$ & 0.31 \\
\hline Average & & $0.77 \%$ & $1.91 \%$ & $196.30 \%$ & 0.41 \\
\hline
\end{tabular}

Source: Author's computations based on eVestment data.

The last table displays the risk-adjusted performance for the four portfolios during the post-crisis periods. SMALL and MODERATE achieved very similar levels of alpha, of $0.22 \%$ and $0.23 \%$, respectively. Sharpe, Treynor and Black-Treynor ratios were the highest for the MODERATE portfolio, followed by the EXPANDED and SMALL portfolios.

Table 7b - Risk-adjusted metrics. Post-crisis period: April 2009 - February 2021

\begin{tabular}{|l|c|c|c|c|}
\hline \multicolumn{1}{|c|}{ Quartile } & Alpha & Sharpe ratio & Treynor ratio & Black-Treynor \\
\hline SMALL & $0.22 \%$ & 0.37 & $1.75 \%$ & $0.44 \%$ \\
\hline MODERATE & $0.23 \%$ & 0.41 & $1.90 \%$ & $0.59 \%$ \\
\hline EXPANDED & $0.19 \%$ & 0.38 & $1.72 \%$ & $0.42 \%$ \\
\hline LARGE & $0.09 \%$ & 0.35 & $1.61 \%$ & $0.30 \%$ \\
\hline \multicolumn{1}{|c|}{ Average } & $0.18 \%$ & 0.38 & $1.75 \%$ & $0.44 \%$ \\
\hline
\end{tabular}

Source: Author's computations based on eVestment data.

\section{Conclusions and discussions}

This paper analyzes the relationship between hedge fund size and its riskadjusted performance. Given the importance of this asset class in the context of the global financial markets and the investors' increasing interest towards the underlying investments of hedge funds and the main determinants of their performance, it is essential to understand what drives performance for these investment vehicles.

Whether size impacts risk-adjusted performance has been the topic of a long-standing debate among both practitioners and academia, with the latter tilting towards an inverse relationship between size and performance (e.g.: Schneeweis et al. 2002, Harri and Brorsen, 2004, Agarwal et al., 2004, Ammann and Moerth, 2005). 
Yet there are studies that document a non-negative or even positive relationship between hedge fund size and performance (e.g.: Gregoriou and Rouah, 2002, Koh et al., 2003, Getmansky, 2004).

The negative relationship between asset size and performance is backed by several arguments, such as: the manager's stock picking ability is hindered once the fund's asset base grows, as the universe is confined to the most liquid assets, hence limiting the exposure of small-capitalization stocks in the investment process; the increase of transaction fees, as more orders have to be executed; the failure of fees to align investors' interests with managers' ones, as a great portion of the management's fee is attributed to the size of the managed asset base (Kouwenberg et al., 2007, Broeders et al., 2019, Escobar-Anel et al., 2020).

On the other hand, there are also arguments for the positive relationship between size and performance, namely, as the hedge fund's asset base increases, synergies may appear among its various departments, thus, improving the overall fund's performance.

Given the theoretical and empirical debate around this issue, this paper contributes to the existing literature by testing the impact of size on the risk-adjusted performance on 245 US hedge funds, classified into eight different investment strategies. The analyzed period spanned from January 2005 to February 2021, as well as three sub-periods to isolate the pre-crisis, crisis, and post-crisis periods. The results fall in line with the previous evidence from the literature (e.g.: Schneeweis et al. 2002, Harri and Brorsen, 2004, Agarwal et al., 2004, Ammann and Moerth, 2005), namely, validating an inverse relationship between size and risk-adjusted performance, for most of the cases.

The portfolio that was constructed in the first quartile, delivered the highest return levels and the highest risk-adjusted performance values, in most of the cases. While the portfolio that was constructed in the fourth quartile, delivered, mostly, the lowest values for the risk-adjusted performance measures. For the whole analyzed period, the average portfolio return reached the highest value, of $0.75 \%$ in the case of the lowest (SMALL) quartile, hence validating the inverse relationship between fund size and return. The same could be said about the funds' registered cumulative return. From January 2005 to February 2021, hedge funds from the first quartile earned $310.6 \%$ in net return, more than doubling the returns from the fourth quartile. When it comes to returns on a risk-adjusted basis, the SMALL portfolio offered the highest alpha level, while the MODERATE portfolio scored the highest Sharpe, Treynor, and Black-Treynor ratios. The LARGE portfolio, which comprises the funds with the highest level of AuM, delivered the lowest risk-adjusted results and registered the lowest alpha level. Similar results were observed for the sub-periods. Thus, it could be concluded that as assets grow, risk-adjusted performance diminishes. Nevertheless, given the complexity of the interaction of all the variables affecting hedge funds' performance, investors should be prudent when choosing the funds to invest in, rather than relying solely on the size characteristics.

Furthermore, an analysis of all the hedge fund's fundamental characteristics, such as size, fees, strategies and age along with their subsequent impact on the risk-adjusted performance could be considered as a future research direction. Also, one aspect that could be deemed as a limitation of my methodology is that the AuM level was taken from the latest date available (reported in February 2021), similar to the method proposed by Gregoriou and Rouah (2002), while the majority of studies 
take into account the average AuM level. This could also be considered as a future research direction together with splitting the database by deciles, instead of quartiles, to analyze how and whether the results will adjust.

To conclude, given the magnitude of the hedge fund industry in the context of the global financial markets, this paper has practical implications as well, as it contributes to the research efforts in the direction of guiding investors in taking the right decision and distributes capital towards the best-performing funds.

\section{Acknowledgements}

Funding: the author acknowledges that this work was supported by a grant of the Romanian Ministry of Education and Research, CNCS - UEFISCDI, project number PN- III-P1-1.1-TE-2019-1702, within PNCDI III.

\section{References}

Agarwal V., Daniel N., Naik N. Y. (2004) Flows, Performance, and Managerial Incentives in the Hedge Fund Industry, Working Paper, London Business School

Amenc N., Sfeir D., Martellini L. (2003) An integrated framework for style analysis and performance measurement, Journal of Performance Measurement, 4 (4), 35 - 41

Ammann, M., Moerth, P. (2005) Impact of fund size on hedge fund performance, Journal of Asset Management, 6 (3), 219-238

Barth D., Joenvaara J., Kauppila M., Wermers R. (2021) The Hedge Fund Industry is Bigger (and has Performed Better) Than You Think, OFR Working Paper 2020/01

Basile I. (2016) Asset Management and Institutional Investors, Springer International Publishing

Black F. (1972) Capital Market Equilibrium with Restricted Borrowing, Journal of Business, 45 (3), 444-455

Black F., Jensen, M., Scholes, M. (1972) The Capital asset pricing model some empirical tests, Studies in the Theory of Capital Markets, 79-121, New York: Praeger

Bodie Z., Kane, A., Marcus, A. J. (2011) Investments. The McGraw-Hill/Irwin, New York

Broeders D. W. G. A., van Oord A., Rijsbergen D. R. (2019) Does it pay to pay performance fees? Empirical evidence from Dutch pension funds, Journal of International Money and Finance, 93, 299-312

Chen J., Hong H., Huang M., Kubik J. D. (2004) Does Fund Size Erode Mutual Fund Performance? The Role of Liquidity and Organization, American Economic Review, 94 (5), 1276-1302

Connor, G. (1995) The three types of factor models: A comparison of their explanatory power, Financial Analysts Journal, 51 (3), 42-46.

Dragomirescu-Gaina C., Philippas D., Tsionas M.G. (2021) Trading off accuracy for speed: Hedge funds' decision-making under uncertainty, International Review of Financial Analysis, 75

Escobar-Anel M., Höhn V., Seco L., Zagst R. (2018) Optimal fee structures in hedge funds, Journal of Asset Management, Palgrave Macmillan, 19 (7), 522-542

Gao C., Haight T., Yin C., Zhang C. (2020) Fund selection, style allocation, and active management abilities: Evidence from funds of hedge funds' holdings, Financial Management, 49, 135 - 159 
Gao C., Haight T., Yin C., Zhang C. (2021) The Performance Life Cycle of Hedge Funds: Can Investors Achieve Lasting Performance?, Social Science Research Network (SSRN), New York, 1-86

Getmansky M., Lo A. W., Makarov I. (2004) An econometric model of serial correlation and illiquidity in hedge fund returns, Journal of Financial Economics, 74 (3), 529-609

Goetzmann W. N., Ingersoll J. E., Ross S. A. (2003) High-Water Marks and Hedge Fund Management Contracts, Journal of Finance, 58 (4), 1685-1718

Gregoriou G. N., Rouah F. (2002) Large versus Small Hedge Funds: Does Size Affect Performance?, Journal of Alternative Investments 5 (4), 22-42

Harri, A., Brorsen B. (2004) Performance persistence and the source of returns for hedge funds, Applied Financial Economics, 14 (2), 131-141

Hedges, J. (2003) Size vs. performance in the hedge fund industry, Journal of Financial Transformation, 10 (1), 14-17

Indro D. C., Christine X., Jiang M., Hu I Y., Wayne Y. L. (1999) Mutual Fund Performance: Does Fund Size Matter?, Financial Analysts Journal 55 (3), 74-87

Jensen M. (1968) The performance of Mutual Funds in the Period 1945-1964, Journal of Finance, 23 (2), 389-416

Jones M. A. (2009) Update to An Examination of Fund Age and Size and Its Impact on Hedge Fund Performance, Journal of Investing, 18 (1), 108-114

Koh F., Koh W. T. H., Teo M. (2003) Asian Hedge Funds: Return Persistence, Style, and Fund Characteristics, Working Paper 1-42. Research Collection Lee Kong Chian School of Business

Kouwenberg R., Ziemba W. T. (2007) Incentives and risk taking in hedge funds, Journal of Banking \& Finance 31 (11), 3291-3310

Lhabitant F. S. (2004) Hedge funds: Quantitative insights. John Wiley \& Sons, Ltd, 177-178

Liang B. (1999) On the Performance of Hedge Funds, Financial Analysts Journal 55 (4), 72-85

Philippas D., Dragomirescu-Gaina C., Goutte S., Khuong N. D. (2021) Investors' attention and information losses under market stress, Journal of Economic Behavior \& Organization 191, 1112-1127

Pollet J., Mungo W. (2008) How Does Size Affect Mutual Fund Behavior?, Journal of Finance 63 (6), 2941-69

Roll R. (1977) A critique of the Asset Pricing Theory's Tests, Journal of Financial Economics 4, 129-176

Schneeweis T., Kazemi H., Martin G. (2002) Understanding hedge fund performance: research issues revisited - Part I. The Journal of Alternative Investments, 5 (3), $6-22$

Sharpe W. (1964) Capital Assets Prices: A Theory of Market Equilibrium Under Conditions of Risk, Journal of Finance, 19 (3), 425-442

Stafylas D., Anderson K., Uddin M. (2016) Recent advances in hedge funds' performance attribution: Performance persistence and fundamental factors, International Review of Financial Analysis, 43, 48-61

Yan X. (2008) Liquidity, Investment Style, and the Relation between Fund Size and Fund Performance, Journal of Financial and Quantitative Analysis, 43 (3), 741-767

Yin C. (2016) The Optimal Size of Hedge Funds: Conflict between Investors and Fund Managers, Journal of Finance, 71 (4), 1857-1893 